E-ISSN. 2685-7650

Vol 3 No 2 (2021) pp 111-118

Artikel Disubmit 11 November 2021 Revisi 29 November $\bullet$ Revisi Diterima 5 Desember

\title{
Representasi Kepemimpinan dalam Film Menolak Diam
}

\author{
M. Abdul Ghofur ${ }^{1}$, M. Yusriansyah Ramadhan ${ }^{2}$, Elang Baskoro Adi ${ }^{3}$ \\ ${ }^{1,2,3}$ Program Studi Ilmu Komunikasi, Universitas Tribhuwana Tunggadewi \\ Email: abdul30ghofur@gmail.com
}

\begin{abstract}
One of the mass communication media (Mass Communication Media) that attracts the public's attention is film. Film is not only a means of creativity, but also a space for actualizing the culture of a society. The purpose of this study is to find out how the director represents leadership on the film of Menolak Diam. The method used in this research is interpretive qualitative with Roland Barthes' semiotic approach. The result shows that the film of "Menolak Diam" has various signs or representations of "leadership", both in verbal and visual forms. These verbal and visual signs are constructed into various scenes, where each scene reflects the meaning of leadership. Apart from that, every piece of dialogue in the film is full of the meaning of leadership. Similar to dialogue, each scene also depicts or represents leadership, especially the figure of Alif as the main character. The scene cuts try to represent the characteristics of a leader that can be seen by the audience.
\end{abstract}

Keywords: film; leadership representation; semiotic

\begin{abstract}
Abstrak: Salah satu media komunikasi massa (Mass Comunication Media) yang banyak menarik perhatian masyarakat adalah film. Film tidak hanya menjadi sarana kreativitas, tetapi juga menjadi ruang aktualisasi kebudayaan suatu masyarakat. Tujuan penelitian ini untuk mengetahui bagaimana sutradara merepresentasikan kepemimpinan dalam film Menolak Diam. Metode yang digunakan dalam penelitian ini adalah kualitatif interpretatif dengan pendekatan semiotika Roland Barthes. Hasil penelitian menunjukkan bahwa film "Menolak Diam" memiliki beragam tanda atau representasi dari "kepemimpinan", baik dalam bentuk verbal maupun visual. Berbagai tanda verbal dan visual tersebut dikonstruksi ke dalam berbagai adegan, di mana setiap adegan mencerminkan makna kepemimpinan. Selain daripada itu, setiap penggalan dialog di dalam film tersebut sarat akan makna kepemimpinan. Sama dengan dialog, setiap adegan juga menggambarkan atau merepresentasikan kepemimpinan terutama pada sosok Alif pemeran utama. Potonganpotongan adegan tersebut mencoba untuk merepresentasikan karakteristik-karakteristik seorang pemimpin yang dapat dilihat oleh para penonton.
\end{abstract}

Kata kunci : film; representasi kepemimpinan; semiotika

\section{Pendahuluan}

Film merupakan salah satu media komunikasi massa (Mass Comunication Media) yang hadir di tengah masyarakat. Film menjadi salah satu teknologi media massa yang banyak menyedot perhatian penontonnya, paling efektif menyampaikan pesan, dan efeknya bekerja tanpa terasa (Setiawati, 2020). Film menjadi sarana aktualisasi kebudayaan masyarakat pada setiap masanya, berpangkal dari setiap realitas masyarakat sehingga dengan sendirinya dapat memenuhi kebutuhan akan kepuasan yang dirasakan penontonnya (Nurliyanti et al., 2018).

Menurut UU No. 33 Tahun 2009 tentang Perfilman Nasional, film sebagai media komunikasi massa merupakan sarana pencerdasan kehidupan bangsa, pengembangan potensi diri, pembinaan akhlak mulia, pemajuan kesejahteraan masyarakat, serta wahana promosi Indonesia di dunia internasional, sehingga film dan perfilman Indonesia perlu dikembangkan dan dilindungi. Film sebagai media komunikasi merupakan sebuah alat atau sarana baru untuk 
memberikan informasi, menghibur, serta bisa juga digunakan untuk menyajikan suatu peristiwa, drama, musik, komedi atau lawak, dan yang lainnya (Astuti, 2018).

Dewasa ini film menunjukkan kenaikan popularitasnya di kalangan masyarakat. Film dapat menjadi medium yang mampu merepresentasikan realitas yang kemudain disajikan kepada audiens (Giovani, 2020; Angela \& Winduwati, 2020). Film adalah teks yang memuat serangkaian citra fotografi yang mengakibatkan adanya ilusi gerak dan tindakan dalam kehidupan nyata (Danesi, 2010).

Setiap film yang diproduksi akan menampilkan suatu pesan yang ditujukan kepada para penonton. Beragam pesan yang dapat terkandung dalam sebuah film, salah satunya adalah pesan kepemimpinan atau leadership. Salah satu film yang merepresentasikan sebuah kepemimpinan yaitu film "Menolak Diam" yang diproduksi Transparancy International Indonesia (TII) berkolaborasi dengan Night Bus Pictures dan juga didukung oleh Embassy of Dennmark in Indonesia. Film ini adalah karya film pendek yang menceritakan kembali sebuah kisah nyata yang pernah terjadi di Solo. Film yang dibintangi oleh Petrus Aji Santoso (Alif), Rahael Ketsia (Nisa), Zed Makarim (Dito), Elang El Gibran (Satrio), dan Kevin Kalagit (Bondan) ini menceritakan bagaimana mereka mencoba untuk mengungkap praktik korupsi yang tengah terjadi di sekolah mereka.

Film merupakan salah satu media yang berpotensi mempengaruhi khalayak karena memiliki kemampuan kekuatan dalam menjangkau segemen sosial yang luas dan banyak (Sobur, 2013). Pengertian lebih lengkap dan mendalam dari film terdapat dalam UU Nomer 8 tahun 1992 pasal 1 ayat (1) tentang perfilman, di mana disebutkan bahwa yang dimaksud dengan film adalah karya cipta seni dan budaya yang merupakan media komunikasi massa pandang dan dengar yang dibuat berdasarkan asas sinematografi dengan direkam pada pita seluloid, pita video, piringan video dan /atau bahan hasil penemuan teknologi lainnya dalam segala bentuk, jenis dan ukuran melalui proses kimiawi, proses elektrinika, atau proses lainnya, dengan atau tabpa suara, yang dapat dipertunjukkan dan/atau ditayangkan dengan system mekanik, elektronikdan/atau lainnya.

Menurut Oey Hong Lee, film merupakan alat komunikasi massa yang muncul pada akhir abad ke-19 (Sobur, 2013). Film merupakan alat komunikasi yang tidak terbatas ruang lingkupnya di mana di dalamnya menjadi ruang ekspresi bebas dalam sebuah proses pembelajaran massa. Kekuatan dan kemampuan film menjangkau banyak segmen sosial, yang membuat para ahli film memiliki potensi untuk mempengaruhi dan membentuk suatu pandangan di masyarakat dengan muatan pesan di dalamnya (Oktavianus, 2015; Wahyuningtyas, 2014). Hal ini didasarkan atas argumen bahwa film adalah potret dari realitas di masyarakat. Film selalu merekam realitas yang tumbuh dan berkembang di dalam masyarakat dan kemudian memproyeksikanya ke dalam layar (Sobur, 2013). Selain itu, film juga memiliki banyak keistimewaan, yaitu (a) dapat menghadirkan pengaruh emosional yang kuat dan sanggup menghubungkan penonton dengan kisah-kisah personal, (b) dapat mengilustrasikan kontras visual secara langsung, (c) dapat berkomunikasi dengan para penonton untuk membuat perubahan, (d) dapat memotivasi penonton untuk membuat perubahan, dan (e) dapat dijadikan alat yang mampu menghubungkan penonton dengan pengalaman yang terpampang melalui bahasa gambar (Javandalasta, 2014).

Secara terperinci, jika dilihat dari jenisnya film dibagi ke dalam beberapa jenis. Pertama, Film Cerita (Fiksi). Film cerita merupakan sebuah film yang diproduksi atau dibuat berdasarkan cerita yang dikarang dan tidak harus sesuai dengan kenyataan atau sebuah fenomena. Film fiksi 
sering menggunakan cerita rekaan di luar kejadian nyata serta memiliki konsep pengadeganan yang telah dirancang sejak awal (Pratista, 2008). Kebanyakan dari film cerita adalah film yang bersifat komersial. Film komersial sendiri diartikan sebagai film yang dipertontonkan di bioskop atau di Televisi. Film yang dipertontonkan di bioskop penonton diharuskan untuk membeli tiket dan film yang dipertontonkan di televisi penayangannya didukung oleh sponsor atau iklan dari produk tertentu.

Kedua, Film Non Cerita (Non Fiksi). Film non cerita atau film non fiksi merupakan film yang mengambil atau dilatarbelakangi sebuah kenyataan atau sebuah fenomena sebagai subjeknya. Film non cerita ini sendiri dibagai menjadi dua kategori, yaitu (a) film faktual dan (b) film dokumenter. Film faktual menampilkan sebuah fakta atau kenyataan. Dewasa ini film faktual dikenal sebagai film berita (news-reel), yang menekankan pada sisi pemberitaan pada suatu kejadian yang aktual. Sedangkan film dokumenter merupakan film yang selain mengandung sebuah fakta atau kenyataan juga mengandung subyektifitas dari para pembuat yang dapat diartikan sebagai sikap atau opini terhadap suatu peristiwa, sehingga persepsi tentang sebuah kenyataan akan sangat tergantung pada sikap dan opini pembuat film dokumenter tersebut (Rikarno, 2015)

\section{Metode Penelitian}

Metode yang digunakan dalam penelitian ini adalah kualitatif interpretatif dengan pendekatan semiotika Roland Barthes. Metode ini menekankan pada penjabaran interpretatif di mana seorang penulis harus mendeskripsikan menggunakan kata-kata berbagai fenomena, sikap individu atau kelompok yang menjadi objek penelitiannya (Machmud, 2016).

Dalam penelitian ini, objek yang digunakan adalah film Menolak Diam yang diproduksi Transparancy International Indonesia (TTI) berkolaborasi dengan Night Bus Pictures. Fokus penelitian ini adalah kepemimpinan atau Leadership. Pada penelitian ini jenis data yang digunakan adalah data primer dan data sekunder. Data Primer dalam penelitian ini berupa foto dari screenshot film Menolak Diam. Data sekunder dalam penelitian ini berupa informasi atau data baik dari buku, jurnal, penelitian terdahulu maupun dari internet.

Teknik pengumpulan data yang akan digunakan adalah teknik dokumentasi. Dokumen yang dapat dijadikan sumber antara lain berupa foto dan data tertulis lainnya (Machmud, 2016). Data berupa potongan-potongan gambar sehingga memudahkan peneliti melakukan analisis terhadap film tersebut. Selain itu peneliti menggunakan literatur yang dapat menunjang serta mendukung penelitian ini, baik yang berasal dari buku, jurnal, penelitian terdahulu maupun dari internet. Data yang diperoleh dianalisa menggunakan teknik analisis semiotika model Roland Barthes. Film Menolak Diam diinterpretasikan menggunakan model ini untuk mengetahui bagaimana kepemimpinan direpresentasikan. Selain itu, berbagai tanda yang ada dalam film dipisahkan menurut strukturnya (penanda dan petanda), yang dalam semiotika Barthes dibagi ke dalam dua tahap tingkat pertandaan, yaitu tingkat denotasi dan konotasi (Machmud, 2016). 


\section{Gambar 1 Bagan Analisis Semiotika Roland Barthes}

\begin{tabular}{|c|c|c|c|}
\hline 1. Signifier & 2. Signified & & \\
\hline \multicolumn{2}{|l|}{ 3. Sign } & \multirow{2}{*}{\multicolumn{2}{|c|}{ Signified }} \\
\hline Signifier & & & \\
\hline
\end{tabular}

Sumber: Peneliti (2021)

\section{Hasil dan Pembahasan}

\section{Representasi Kepemimpinan Dalam Film "Menolak Diam"}

Kajian mengenai kepemimpinan kerap hadir dalam media seperti film, dan juga dalam kegiatan sehari-hari. Kepemimpinan merupakan kegiatan untuk mempengaruhi perilaku orang lain agar mereka bekerja sama menuju kepada tujuan tertentu yang mereka inginkan (Potu, 2013; Ajefri, 2017). Artinya, kepemimpinan adalah sebuah perilaku dari seorang individu yang memimpin aktivitas-aktivitas suatu kelompok ke suatu tujuan yang ingin diciptakan bersama.

Dalam menjalankan tugas sebagai seorang pemimpin, ternyata tugas pemimpin dalam menjalan misi organisasi tidaklah mudah, karena untuk menjalankan misi tersebut ia harus memiliki persyaratan untuk menjadi seorang pemimpin yang bertanggung jawab terhadap segala tugas yang diembannya untuk memenuhi tujuan dari organisasi yang dipimpinnya. Kepemimpinan seperti ini juga yang ditampilkan dalam film Menolak Diam.

\section{Scene 1}

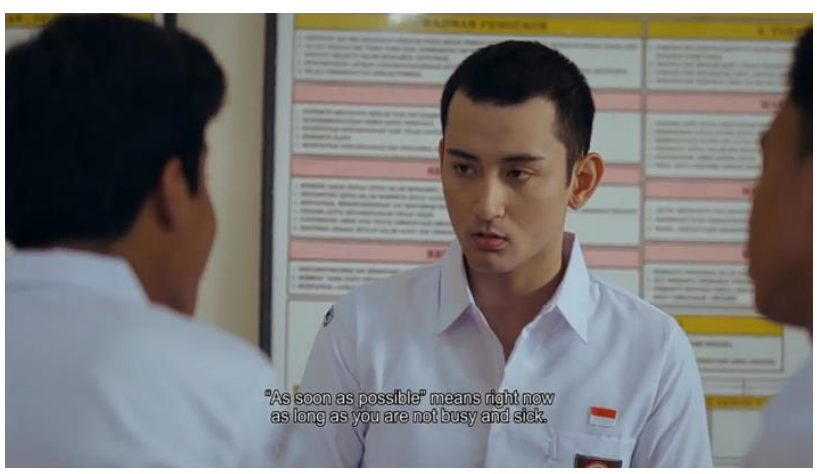

Gambar 2 Scene yang menunjukkan Alif memberikan arahan kepada Bondan

Scene ini menggunakan teknik pengambilan gambar medium shot, menggambarkan situasi dimana Alif sedang memberikan arahan kepada bondan. Percakapan atau dialog pada scene ini menggambarkan situasi dimana Alif memiliki kemampuan untuk memberikan arahan kepada orang lain agar mereka mau melakukan apa yang alif inginkan. Scene ini menggunakan backsound dramatic dengan tujuan untuk menunjukkan bahwa situasi yang terjadi saat itu adalah situasi yang genting. Selain itu, juga menggunakan natural sound, menggambarkan bahwa situasi tersebut atau adegan tersebut terjadi di lingkungan persekolahan. 
Makna Denotasi: Dalam scene ini Nampak Alif dan satrio sedang bertemu dan menyampaikan aspirasinya kepada ketua osis (Bondan) mengenai ditiadakannya wisuda pada tahun itu. Alif dengan tegas memberikan arahan kepada Bondan yang saat itu hanya menyanggupi tanpa memberikan kepastian kapan akan disampaikannya aspirasi tersebut. Dengan jelas pulas Alif mengatakan "secepatnya adalah sekarang selama dia tidak sakit atau sedang sibuk".

Makna Konotasi: Pengambilan gambar medium shot dalam scene ini yang bermaksud untuk menggambarkan situasi dimana sedang terjadi percakapan antara Alif dan Bondan, dengan pengambilan gambar medium shot pula dapat ditampilkan secara jelas bagaimana ekspresi Alif yang lebih tegas dari pada Bondan. Dalam scene ini menggambarkan seorang pemimpin dengan karakteristik tegas dan memiliki inteligensi yang lebih baikn dari pada orang lain. Pada scene ini pula digambarkan Alif yang sedang berjuang agar aspirasinya segera disampaikan kepada kepala sekolah.

Dengan demikian, mampu memberikan arahan kepada seseorang merupakan salah satu indikasi bahwa orang tersebut memiliki karakter sebagai pemimpin, Menurut Burt Nanus yang dikutip lembaga Pendidikan dan Pengembangan Manajemen Jakarta. Seorang pemimpin diharapkan dapat berperan sebagai seseorang yang mampu memberi pengarahan, sehingga dapat diketahui sampai sejauh mana efektifitas maupun efisiensi pelaksanaan dalam upaya pencapaian tujuan. Dalam scene 1 ini digambarkan bahwa sosok Alif merupakan seseorang yang mampu memberikan arahan kepada Bondan. Hal ini juga didukung dengan ekspresei wajah Alif yang lebih dominan daripada Bondan yang terlihat seperti sedang mendengarkan arahan dari Alif. Dengan nada suara yang lebih tegas alif mampu memberikan arahan kepada bondan, selain nada suara yang lebih tegas postur tubuh alif yang digambarkan sedang menggebrak meja sambil menunjukkan kertas pengumuman bahwa ditiadakannya wisuda membuktikan bahwa sosok alif digambarkan memiliki sifat yang lebih tegas dan memiliki inteligensi yang lebih baik dari pada Bondan.

Ada beberapa faktor tertentu yang dapat mempengaruhi proses kepemimpinan dalam suatu organisasi salah satu yang sangat menonjol adalah inteligensi (Ardana \& Mujiati, 2009). Umumnya pemimpin akan mempunyai taraf inteligensi yang lebih tinggi dari pada yang dipimpin. Selain itu ada karakteristik lain seperti kecerdasan, memotivasi dan tegas.

\section{Scene 2}

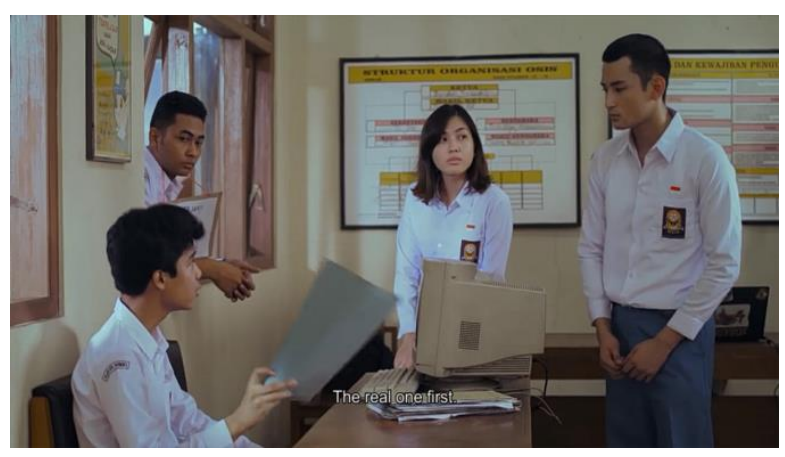

Gambar 3 menunjukkan Alif, Nisa dan Dito sedang mengambil keputusan apa yang akan mereka lakukan 
Pengambilan gambar pada scene ini menggunakan teknik medium shot. Dialog pada scene ini menggambarkan bagaimana Alif, Nisa, Bondan dan ditto mengambil keputusan atas apa yang mereka akan lakukan. Hampir sama dengan scene 1, dalam scene 2 ini juga menggunakan backsound yang dramatic, hal ini ditujukan agar adegan yang ditampilkan dapat menghadirkan situasi yang menghadirkan situasi yang mengejutkan dengan mereka menemukan kassus korupsi yang sedang terjadi di sekolah mereka. Juga terdapat sound effect di tengah-tengah adegan.

Makna Denotasi: Dalam scene ini Nampak Alif dan satrio sedang bertemu dan menyampaikan aspirasinya kepada ketua osis (Bondan) mengenai ditiadakannya wisuda pada tahun itu. Alif dengan tegas memberikan arahan kepada Bondan yang saat itu hanya menyanggupi tanpa memberikan kepastian kapan akan disampaikannya aspirasi tersebut. Dengan jelas pulas Alif mengatakan "secepatnya adalah sekarang selama dia tidak sakit atau sedang sibuk".

Makna Konotasi: Pengambilan gambar medium shot dalam scene ini yang bermaksud untuk menggambarkan situasi dimana sedang terjadi percakapan antara Alif dan Bondan, dengan pengambilan gambar medium shot pula dapat ditampilkan secara jelas bagaimana ekspresi Alif yang lebih tegas dari pada Bondan. Dalam scene ini menggambarkan seorang pemimpin dengan karakteristik tegas dan memiliki inteligensi yang lebih baikn dari pada orang lain. Pada scene ini pula digambarkan Alif yang sedang berjuang agar aspirasinya segera disampaikan kepada kepala sekolah.

Scene ini dapat dijelaskan bahwa Alif merupakan seorang siswa yang mampu mengambil keputusan dengan cepat dan tidak hanya cepat alif mengambil keputusan yang baik dan tepat. Hal ini dapat dilihat pada adegan yang digambarkan pada scene 2 ini. Dalam scene ini Alif mengambil keputusan yang baik dan tepat, dan lebih cepat daripada Nisa, Bondan dan Dito yang pada saat itu sama-sama memikirkan bagaimana cara yang cepat untuk membongkar praktik korupsi yang sedang terjadi di sekolahnya. Merujuk pada teori kepemimpinan menurut Siagian (2003) ciri-ciri dari seorang pemimpin salah satunya adalah memiliki kemampuan analitik yang baik dan cepat.

Kemampuan analitik yang baik dan cepat juga mempengaruhi bagaimana seseorang bersikap terhadap sebuah masalah atau kejadian. Dan hal inilah yang menentukan seseorang dalam mengambil sebuah keputusan dalam setiap keadaan. Dan hal ini juga sudah tergambar dalam scene ini dimana Alif dapat menentukan dan mengambil keputusan lebih cepat dan lebih baik daripada teman-temannya.

\section{Scene 3}

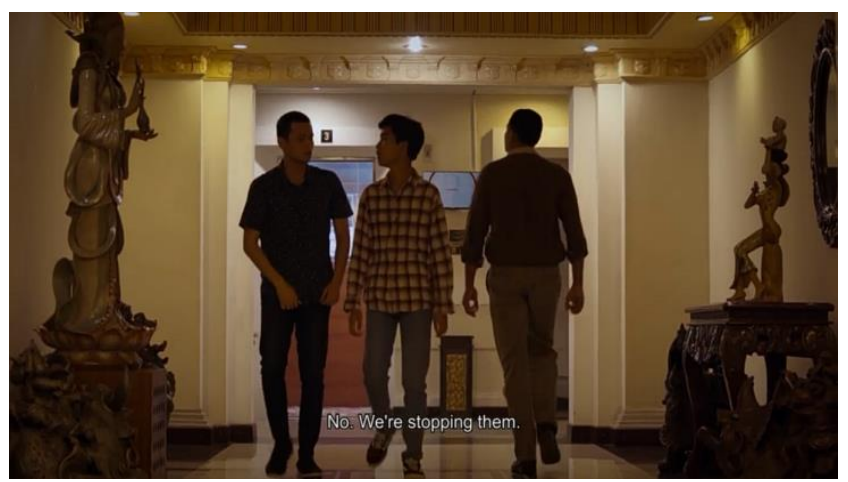

Gambar 4 menunjukkan Alif memiliki sifat bertanggung jawab 
Pada scene ketiga ini adegan digambarkan dengan menggunakan teknik long shot, hal ini bertujuan untuk menunjukkan suasana ketegasan dan sikap tanggung jawab dari Alif. Dialog pada scene ini menggambarkan Alif merupakan siswa yang sudah memiliki rasa tanggung jawab yang tinggi kepada temannya, rasa tanggung jawab sendiri juga merupakan salah satu dari karakteristik dari seorang pemimpin. Menggunakan dramatic backsound dalam scene ini menggambarkan ketegasan Alif dan situasi yang semakin memanas diantara Alif, Nisa, Bondan dan Dito. Suara binatang-binatang malam seperti katak dan jangkrik semakin menggambarkan situasi yang sunyi dan suasana malam hari di sekolah.

Makna Denotasi: Dalam scene ini Nampak Alif dan Bondan sedang berjalan dan membicarakan tentang Nisa dan Dito sedang mencuri Laporan APBS di ruang kepala sekolah mereka. Mengetahui hal tersebut Alif mencoba untuk menghentikan tindakan Nisa dan Dito.

Makna Konotasi: Pengambilan gambar Long shot dalam scene ini yang bermaksud untuk menggambarkan situasi dimana Alif dengan tegas ingin menghentikan tindakan Nisa dan Dito yang ingin mencuri laporan APBS di ruangan kepala sekolah di sekolah mereka. Dengan tindakan yang dilakukan oleh Alif dalam adegan ini sudah menggambarkan rasa tanggung jawab terhadap temannya agar tidak melakukan tindakan yang salah. Hal ini merupakan salah satu kriteria dari sorang pemimpin yang merasa bertanggung jawab terhadap semua yang dilakukan oleh bawahannya.

Pada scene ini digambarkan bahwa tidak semua orang memiliki sifat atau rasa tanggung jawab yang tinggi, oleh karena itu orang yang memiliki sifat tersebut merupakan salah satu orang yang dapat dijadikan sebagai pemimpin, seorang pemimpin yang memiliki tanggung jawab yang tinggi akan dapat membimbing anggotanya. Hal ini juga dapat dilihat dalam karakter Alif, Alif yang sejatinya masih seorang siswa SMA saja sudah memiliki rasa tanggung jawab yang tinggi terhadap teman-temannya. Dapat dilihat dari adegan atau scene diatas, yang menunjukkan alif memiliki sifat tersebut.

Penggambaran dalam adegan di atas ditekankan dengan adegan Alif yang dengan beraninya menyatakan bahwa tindakan yang dilakukan oleh Nisa dan Dito adalah tanggung jawabnya, walaupun bukan dia yang melakukannya. Meski hal tersebut akan membawa Alif kepada kenyataan yang tidak mengenakkan bagi dirinya sendiri, Alif mau berkorban demi temantemannya agar mereka tidak melakukan tindakan yang salah.

\section{Kesimpulan}

Film "Menolak Diam" memiliki beragam tanda atau representasi "kepemimpinan" di dalamnya, baik dalam bentuk verbal maupun visual. Bentuk verbal berupa dialog antara setiap tokoh dan dalam bentuk visual digambarkan dalam bentuk gestur paupun ekspresi dari setiap tokoh yang ada dalam film tersebut. Melalui berbagai tanda verbal dan visual, kemudian ditemukanlah makna kepemimpinan yang dikonstruksi ke dalam film tersebut. Setiap penggalan dialog yang ada di film tersebut sarat akan makna kepemimpinan. Sama halnya dengan dialog, setiap scene dalam film ini juga menggambarkan atau merepresentasikan kepemimpinan terutama pada sosok Alif. Scene-scene dalam film tersebut berusaha merepresentasikan karakteristikkarakteristik seorang pemimpin yang dapat dilihat oleh para penonton.

\section{Daftar Pustaka}

Ajefri, F. (2017). Efektifitas Kepemimpinan dalam Manajemen Berbasis Madrasah. Jurnal 
Kependidikan Islam, 7(2), 100-119.

Angela, M., \& Winduwati, S. (2020). Representasi Kemiskinan dalam Film Korea Selatan (Analisis Semiotika Model Saussure pada Film Parasite). Koneksi, 3(2), 478-484. https://doi.org/10.24912/kn.v3i2.6480

Ardana, I. K., \& Mujiati, N. W. (2009). Perilaku Keorganisasian. Graha Ilmu.

Astuti, R. D. (2018). Resepsi Film Hachiko Monogatari Sebagai Sarana Hiburan. Janaru Saja: Jurnal Program Studi Sastra Jepang, 7(2), 52-60.

Danesi, M. (2010). Pengantar Memahami Semiotika Media. Jalasutra.

Giovani, G. (2020). Representasi "Nazar" dalam Film Insya Allah Sah Karya Benni Setiawan. PROPORSI: Jurnal Desain, Multimedia Dan Industri Kreatif, 5(2), 227-238. https://doi.org/10.22303/proporsi.2.1.2016.59-70

Javandalasta, P. (2014). Lima Hari Mahir Bikin Film. Mumtaz Media.

Machmud, M. (2016). Tuntunan Penulisan Tugas Akhir Berdasarkan Prinsip Dasar Penelitian Ilmiah. Selaras.

Nurliyanti, S., Rande, S., Qamara, A. E., Tenggelamnya, F., Wijck, K. Van Der, \& Patriarki, B. (2018). Representasi Budaya Patriarki dalam Film Tenggelamnya Kapal Van Der Wijck. EJournal Lmu Komunikasi, 6(3), 291-305.

Oktavianus, H. (2015). Penerimaan Penonton Terhadap Praktek Eksorsis Di Dalam Film Conjuring. E-Komunikasi, 3(2), 1-12.

Potu, A. (2013). Kepemimpinan, Motivasi, dan Lingkungan Kerja Pengaruhnya Terhadap Kinerja Karyawan Pada Kanwil Ditjen Kekayaan Negara Suluttenggo dan Maluku Utara di Manado. Jurnal Riset Ekonomi, Manajemen, Bisnis Dan Akuntansi, 1(4). https://doi.org/10.35794/emba.v1i4.2894

Pratista, H. (2008). Memahami Film. Homerian Pustaka.

Rikarno, R. (2015). Film Dokumenter Sebagai Sumber Belajar Siswa. Ekspresi Seni, 17(1), 129149. https://doi.org/10.26887/ekse.v17i1.71

Setiawati, T. (2020). Representasi Budaya Patriarki Dalam Film Istri Orang. KOMUNIKA, 7(2), 66-76. https://doi.org/10.22236/komunika.v7i2.6328

Sobur, A. (2013). Semiotika Komunikasi. Remaja Rosdakarya.

Wahyuningtyas, B. P. (2014). Representasi Kekuatan, Kecerdasan, dan Cita Rasa Perempuan: Analisis Wacana pada Film "The Iron Lady." Humaniora, 5(1), 28-38. https://doi.org/10.21512/humaniora.v5i1.2978. 